\title{
Investigation of Copper removal mechanisms on Quercus robur acorn caps: Equilibrium, kinetics, thermodynamic and characterization studies
}

\author{
Zafer Zeybek $^{1}$ (1) $\cdot$ Sukru Dursun² ${ }^{2}$
}

Received: 20 May 2020 / Accepted: 19 May 2021 / Published online: 3 June 2021

(c) The Author(s) 2021

\begin{abstract}
Intended for human consumption water resources are rapidly decreased due to overuse, global warming and also polluting by pollutants. Metal concentrations are generally removed by precipitation, adsorption, biosorption and some chemical reactions in the receiving water media. Therefore, polluted waters by metals are caused to rarely toxic effects in living things in high concentrations. Metal polluted waters are generally caused to esthetic and cosmetic effects. Adsorption is one of the commonly used methods for metal removal. In recent years, researches about natural low cost adsorbents are increased. Factors such as modification and electricity costs increase the cost of adsorbent. In this study, dry acorn caps of Quercus robur were used as non-modify natural adsorbent. The batch experiments were carried out to removal of copper in water that has initial low concentration by prepared natural adsorbent. It was performed equilibrium, kinetics, thermodynamic studies and moreover adsorbent characterization studies with using SEM + EDX and XRD methods. It was found the removal efficiency was $84 \%$, and adsorption capacity was $0.336 \mathrm{mg} / \mathrm{g}$. This paper is aimed to expressing the affecting factors of adsorption mechanism at the removal of copper in water. This paper is expressing the affecting factors of a non-modify natural adsorbent's adsorption mechanism at the removal of copper in water which has initial low concentration. As a consequence, it has been seen that acorn caps of Quercus robur due to contained tannins highly effects adsorption mechanism, and it may be used of copper removal.
\end{abstract}

Keywords Adsorption mechanism · Copper · Low cost adsorbents · Low initial concentration · Tannins effect · Water pollution $\cdot$ Quercus robur

\section{Introduction}

Water resources have been polluted by various polluting factors and water pollution occurs. While Verma et al. (2013) describe water pollution as contamination in liquid-containing areas, Weiner (2008) defined it as the presence of beneficial or harmful substances different from water $\left(\mathrm{H}_{2} \mathrm{O}\right)$ in a

Zafer Zeybek

zaferzeybek70@hotmail.com

Sukru Dursun

sdursun@ktun.edu.tr

1 Turkish Ministry of Health, Aydın Public Health Laboratory, 09100 Aydin, Turkey

2 Department of Enviromental Engineering, Faculty of Engineering and Natural Sciences, Konya Technical University, 42003 Konya, Turkey water sample. According to him, impurities are divided into three classes: esthetically hazardous and harmful impurities, impurities that are not considered as harmful and potential health risks that have not been evaluated yet. He states that six characteristics are very important in estimating the environmental impact of a pollutant. These are: water solubility, volatility, density, chemical reactivity, biodegradability and the ability to hold solids.

Rapid population growth and intensive industrialization have increased the use pressure on water resources, and water resources have started to be polluted rapidly with various pollutants, such as metals that can reach from surface waters to groundwater. Along with the hydrological cycle, metals can reach from surface waters to groundwater. Domestic, agricultural and industrial wastewaters that reach aquatic areas by the insufficient treatment or non-treatment cause metal pollution and contaminate drinking and utility water resources as well as access to groundwater. 
Copper is one of the common metals, hence intensive used at wide variety industry, such as electric-electronic, transportation, chemical, paint, food, fertilizers, pesticide, etc. Copper pollution in waters generally consists of wastewater from mining and industrial activities or geological structure. Dursun et al. (2011) emphasized that copper is frequently found in surface waters because it is a metal that can be found everywhere in the environment. Copper in surface waters can be complexed with dissolved organic substances, adsorbed and precipitated with sediments and other colloidal materials and even biosorbed by aquatic organisms. Therefore, toxic effects of copper are less common in surface waters than in groundwater. Aquatic flora and fauna in fresh waters are more sensitive to the toxic effects of copper and as the $\mathrm{pH}$ drops, copper toxicity increases (Zeybek 2019). In fact, copper is an essential nutrient for all living things, including humans, however high doses can cause liver and kidney damage (Chakravarty et al. 2008; Gautam et al. 2015), as well as effect on neurodegenerative diseases such as Alzheimer's and Parkinson's (Bondy et al. 2018). Brewer (2012) believes that Alzheimer's disease is sourced by inorganic copper ingested from the drinking waters. Limit values in drinking water for copper are $2 \mathrm{mg} / \mathrm{L}$ (WHO 2011), $1.3 \mathrm{mg} / \mathrm{L}$ for primary standards (USEPA 1998) and $1 \mathrm{mg} / \mathrm{L}$ for secondary standards (USEPA 2017). Legal regulations and recommendations in waters for copper are described in detail in the previous study (Zeybek et al. 2019). Moving from the fact that water is a scarce resource it is very important that the water used, as well as the effective use of water, become reusable. Therefore, effective treatment methods should be used to minimize pollutants.

There are several treatment methods used for the removal of copper in water. Oguz (2015) suggested the combined use of methods coagulation, flocculation, filtration (up to $2 \mathrm{mg}$ $\mathrm{Cu} / \mathrm{L}$ ) and the lime softening, ion exchange (IE), reverse osmosis (RO) methods (up to $10 \mathrm{mg} \mathrm{Cu} / \mathrm{L}$ ) for the treatment of copper in drinking waters for Turkey. Regarding copper removal techniques in industrial wastewater; Al-Saydeh et al. (2017) stated that adsorption, cementation, membrane filtration (ultrafiltration (UF)), nano-filtration (NF and RO), electrochemical methods (electrocoagulation (EC), electrodialysis (ED)) and photocatalysis methods are used. These methods have been examined by many researchers using various materials. These: Reduction-coagulation using micro aluminum composites (Bojic et al. 2009); EC using aluminum electrodes (Heidmann et al. 2008), iron electrodes (Al-Shannag et al. 2015); ED using polymer ion exchange membrane (Caprarescu et al. 2014); Photocatalysis using Fenton reactive (Argun et al. 2009; Azhdarpoor et al. 2015). However, it has been stated that the application of these methods, except for adsorption, will be expensive and inefficient when the metal concentration is below $100 \mathrm{ppm}$, and a large amount of waste is generated, therefore adsorption will be advantageous at low concentrations of metals (Acar et al. 2006; Kumari et al. 2015; Celebi et al. 2017a).

Adsorption is a progressed treatment method with using a material that is called adsorbent or sorbent, which permits the decontamination of miscellaneous pollutants at much lower cost than other strategies. Regarding the classification of adsorbents; approach differences exist due to reasons such as the study areas of different scientific disciplines, the way adsorbent is obtained, the structure of the adsorbent, the purpose of the adsorbent and the cost. In its most general sense, an adsorbent should be separated based on whether it is natural or synthetic (Zeybek 2019;). Known commercial adsorbents such as activated carbon, zeolite, silica gel and ion exchange resins, also called engineering adsorbents (Worch 2012) or conventional adsorbents (Crini et al. 2019), have long been used for metal removal (Ozcan et al. 2018). However, due to the costs, regeneration and waste problems of commercial adsorbents, researches on cheap cost natural adsorbents have become necessity and increased in recent years. Natural adsorbents are consist of natural materials, bio-sorbents, agricultural, forestry and industrial products and their by-products and wastes and called with various names, such as low cost adsorbents (LCAs) (Worch 2012; Iakovleva et al. 2013; De Gisi et al. 2016; Acar et al. 2006; Kumari et al. 2015; Celebi 2020a), non-conventional adsorbents ( Khan et al. 2008; Crini et al. 2019), green adsorbents (Kyzas et al. 2014) and new adsorbents (Krstić et al. 2018). It has been reported many more studies related to copper removal studies with natural adsorbents. Examples from some studies as it can be given that high quality limestone (Aziz et al. 2008), natural zeolites (Dursun et al. 2011), acidactivated clays (Bhattacharyya et al. 2011), Escherichia coli (Ravikumar et al. 2011), watermelon seed hulls (Akkaya et al. 2013), waste biomass adsorbents (Bilal et al. 2013), combine tea wastes and dolomite mix (Albadarin et al. 2014), modified tangerine peel (Abdić et al. 2018), agricultural solid wastes (Afroze et al. 2018).

There are also removal studies that have been carried out copper, other metals and pollutants focused on Quercus robur and other Quercus species, such as total $\mathrm{Cr}$ and $\mathrm{Cr}(\mathrm{VI})$ removal with Quercus robur acorn peel (Kuppusamy et al. 2016), cationic dye removal with Quercus robur acorn peel (Kuppusamy et al. 2017), Zn(II), Cu and Al (III) removal with Quercus robur acorn cap (Zeybek 2019), copper removal with Quercus robur acorn cap (Zeybek et al. 2019), $\mathrm{Cu}, \mathrm{Ni}$ and $\mathrm{Cr}$ removal with Quercus coccifera sawdust (Argun et al. 2007), dyes and Cr (VI) removal with Quercus alegilops valonea and Pinus pinea cone pulp mix (Berraksu et al. 2012), Cr(VI) and total chromium removal by acorn shell of Quercus crassipes Humb. \& Bonpl (Aranda-García et al. 2014). In the mentioned studies, the adsorption mechanism is realized with hydroxylic, carboxylic and phenolic compounds such as 
tannins in the structure of the materials used as adsorbents. There are also studies using polyhydroxy phenols and thus reducing the properties of tannins, such as $\mathrm{Cu}$ (II) removal with valonia tannin resin (Șengil et al. 2009), Au (III) ions reducing with hydroxyphenol derivatives (Lee et al. 2011), aluminum and lead removal with chitosan-tannic acid modified biopolymers (Badawi et al. 2017).

Considering the literature data, the number of studies carried out at low initial concentration is extremely low in the copper removal from water by adsorption. However, copper is present in lower concentrations in water sources due to chemical precipitation and adsorption. Therefore, it must be carried out to comply with the concentration values in legal regulations. Another important issue is that it is still known as low cost adsorbent although it is known that the cost of adsorbent increases by modifying natural adsorbents in various ways. On the other hand, the relationship between adsorbent and cost after the use of modified adsorbents has not been studied in many studies. Kyzas et al. (2014) suggested that the cost of modification should also be taken into account in the techno-economic analysis of adsorbents and reported that it is better to make green adsorbents used for adsorption only with adsorbents obtained by washing agricultural waste instead of activated carbon obtained from agricultural waste. Gautam et al. (2015) explained the reason for the modification of biosorbent materials as providing mechanical strength and resistance to chemical and microbiological degradation and increasing the biosorption selectivity for target metals. However, it has been reported in some studies that the unmodified adsorbent has a higher (Kehinde et al. 2009; Ashwini et al. 2018) or closer (Yahaya et al. 2016) adsorption capacity than the modified adsorbent. Therefore, the main point of this study is to examine the removal of copper at low initial concentrations with unmodified natural adsorbent.

In the previous study (Zeybek et al. 2019), the parameters affecting the adsorption $(\mathrm{pH}$, initial metal concentration, temperature, contact time, adsorbent dose, shaking speed and adsorbent size) on the copper removal with the acorn cap adsorbent that obtained Quercus robur were examined, and the adsorbent was characterized by SEM + EDX (Scanning Electron Microscopy and Energy Dispersive X-ray Spectroscopy) and XRD (X-ray Diffraction) analysis. And, it has been determined that the non-modified acorn cap adsorbent can be used as low cost adsorbent in copper removal at low concentrations.

In this study, it was aimed to investigate the effect of tannins on adsorption by calculating kinetic and thermodynamic parameters with suitable adsorption isotherms in removing copper with non-modified acorn cap adsorbent that obtained Quercus robur at low initial concentrations in copper removal.
The study was carried out at the Selcuk University and Konya Technical University, Departments of Environmental Engineering, Konya-Turkey and some parts Public Health Laboratory and Karamanoglu Mehmet Bey University BILTEM laboratory, Karaman-Turkey from February 2018 to July 2019.

\section{Materials and methods}

\section{Preparation of adsorbent and laboratory experiments}

The adsorbent used in this study is of organic nature; It was obtained from the acorn caps of Handle Oak (Quercus robur L.) that present in Karaman/Turkey. The collected samples were separated from their stems, washed with distilled water and dried in the open air. Dry samples were ground with a mill and shaken by sieves and separated into particle sizes. The natural adsorbent material prepared was called $\mathrm{P}$ and was stored in glass containers in an airtight manner.

For the preparing of solutions, $0.1,0.5,1.0,1.5,2.0$ and $2.5 \mathrm{mg} / \mathrm{L}$ solutions from $10 \mathrm{mg} / \mathrm{L}$ stock solution were prepared using $1000 \mathrm{ppm} \mathrm{Cu}$ standard solution (MerckCertipur ${ }^{\circledR}$ ). $0.1 \mathrm{~N} \mathrm{HCl}$ (Merck) and $0.1 \mathrm{~N} \mathrm{NaOH}$ (Merck) solutions were used for $\mathrm{pH}$ adjustments. To determine the copper concentration, a UV-Vis spectrophotometer, and Hach Lange $\mathrm{CuVer} 1$ reactive tests were used according to the copper test procedure (Anonymous 2017) that adapted from USEPA Bicinchonitate Method. In this method, copper measurement range, $0.04-5.0 \mathrm{mg} / \mathrm{L}$ and wavelength, $560 \mathrm{~nm}$. In all tests, the blank is prepared with the sample taken from the solution, and reagents are added to the sample, and measurement is made after a certain period of time. This ensures that problems such as slight turbidity and color caused by the solution are eliminated. Control experiments with pure water and method performance experiments with $1 \mathrm{mg} / \mathrm{L}$ standard copper solution were confirmed the accuracy of the method. The batch experiments were carried out according to the bottle-point method (Worch 2012), and equilibrium data were determined. Each flask was filled with the $\mathrm{Cu}$ solution, $100 \mathrm{~mL}$ and initial copper concentration, $2 \mathrm{mg} / \mathrm{L}$. After, adding $\mathbf{P}$ adsorbent mass, $0.5 \mathrm{~g}$, the solution was stirred until the state of equilibrium is reached. Figure 1 is shown the design of the experiment from the preparation of the adsorbent to the detection of the adsorption mechanism.

In this study, the devices used for the experiments were: UV-visible spectrophotometer (Hach Lange Dr.2800 and Dr.3900 models), pH device (WTW multi720), shaking incubator (ZHWY-200B), orbital shaker (Heidolph-unimax 1010), precision balance (Precisa 205A), vacuum pump (SARTORIUS-Microsart ${ }^{\circledR}$ e.jet) and drying oven (NUVE 


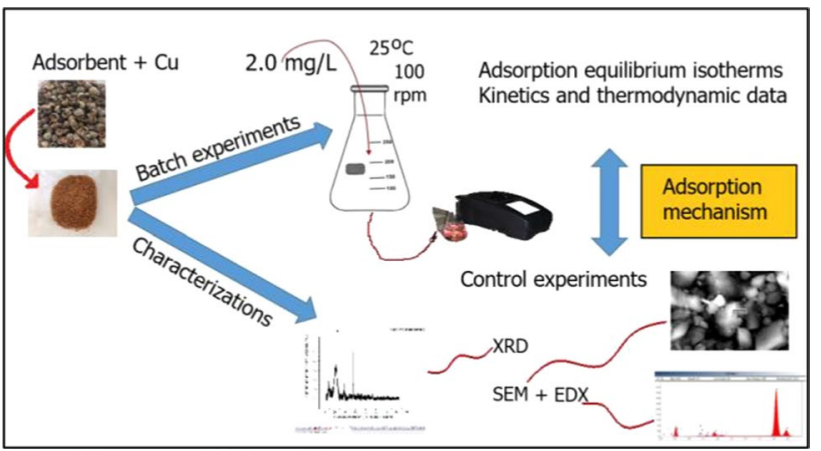

Fig. 1 Schematic representation of the experimental design

F 500). Many lab equipment was used for the analysis, such as flasks (250-500 mL), balloon flask (100-500-1000 mL), automatic pipette $(1-5 \mathrm{~mL})$ and tips, graduated cylinder (25-50-100 mL), filter papers (Whatman, $125 \mathrm{~mm}$ ), parafilm, etc.

\section{Equilibrium isotherm studies}

Linearized Langmuir, Freundlich, D-R and Temkin isotherms were applied to determine the fit adsorption model based on the removal data in this study. In the calculation of adsorption isotherms; $\mathrm{pH} 7$, initial concentration of $2 \mathrm{mg}$ $\mathrm{Cu} / \mathrm{L}$, temperature of $25^{\circ} \mathrm{C}, 60 \mathrm{~min}$ contact time, $300 \mu$ adsorbent size, $100 \mathrm{rpm}$ mixing speed, range of $0.1-1.0 \mathrm{~g}$ adsorbent dose was studied at the optimum experimental conditions.

The equations used in the calculation of linearized Langmuir, Freundlich, D-R and Temkin isotherms are given in Eq. (1), (2), (3) and (4), respectively. In addition, Langmuir model dispersion constant $R_{L}$ equality (1.1), D-R model for the adsorption energy $\mathrm{E}$ (3.1) and all adsorption experiments $\%$ removal efficiency ( $\%$ ) is given in (5).

Langmuir isotherm is expressed by the following linearized equation (Argun et al. 2007). $C_{e} / q_{e}$ versus $C e$ is plotted, and $1 / K$ is obtained from the slope of the obtained line and $1 / b K$ from the point where the line intersects the $C_{e} / q_{e}$ axis. Here, qe represents the amount of metal retained per one adsorbent weight when the system is in equilibrium; $C_{e}(\mathrm{mg} / \mathrm{L})$ equilibrium metal concentration, $b(\mathrm{mg} / \mathrm{g})$ and $K(\mathrm{mg} / \mathrm{L})$ denote Langmuir constants related to adsorption capacity and energy, respectively. Langmuir isotherm is calculated according to Eq. (1).

$\left(C_{e} / q_{e}\right)=(1 / b K)+\left(C_{e} / b\right)$

In order to find the convenience of adsorption, dimensionless $R_{L}$ (dispersion) constant is calculated, and this constant takes values between 0 and 1 indicating that the availability is provided The dispersion constant is calculated according to the Eq. (2) and isotherm types according to $R_{L} ; R_{L}>1$ is considered unfavorable, $R_{L}=1$ linear, $0<R_{L}<1$ favorable and $R_{L}=0$ irreversible (Bayat 2002). Here, b (mg/g) adsorption capacity and $C_{o}(\mathrm{mg} / \mathrm{L})$ initial concentration.

$R_{L}=1 /\left(1+b C_{o}\right)$

Freundlich isotherm is expressed by the following linearized equation (Argun et al. 2008). If $\log q_{e}$ versus $\log C_{e}$ is plotted, $1 / n$ is obtained from the slope of the obtained line, and the $\log K_{f}$ value is obtained from the point where the line intersects the $\log q_{e}$ axis. Here, $q_{e}$ represents the amount of metal retained per unit adsorbent weight when the system is in equilibrium; $C e(\mathrm{mg} / \mathrm{L})$ equilibrium metal concentration; $K_{f}$ $(\mathrm{mg} / \mathrm{g})$ and $n(\mathrm{mg} / \mathrm{L})$ express Freundlich constants. Freundlich isotherm is calculated according to Eq. (3).

$\log q_{e}=\log K_{f}+(1 / n) \log C_{e}$

D-R isotherm is expressed by the following linearized equation (Argun et al. 2007). If ln qe is plotted versus $\varepsilon^{2}, K^{\prime}$ is calculated from the slope of the obtained line, and $\ln X_{m}^{\prime}$ is calculated from the point at which the line intersects the $\ln q_{e}$ axis. D-R isotherm is calculated according to Eq. (4). In addition, adsorption energy $(E ; \mathrm{kJ} / \mathrm{mol})$, which gives information about the physical or chemical characteristics of adsorption by $\mathrm{D}-\mathrm{R}$ isotherm, is calculated by Eq. (4). Here, $\varepsilon$ (Polanyi potential) $=\mathrm{RT} \ln \left(1+1 / C_{e}\right), X^{\prime}{ }_{m}$ adsorption capacity $(\mathrm{mg} / \mathrm{g}), K^{\prime}$ adsorption energy constant $\left(\mathrm{mol}^{2} \mathrm{~kJ}^{-2}\right)$, $\mathrm{R}$ ideal gas constant $(8.314 \mathrm{~J} / \mathrm{mol} \mathrm{K})$ and $\mathrm{T}$ temperature $\left({ }^{\circ} \mathrm{K}\right)$.

$\ln q_{e}=\ln X_{m}^{\prime}-K^{\prime} \varepsilon^{2}$

$E=\left(-2 K^{\prime}\right)^{-1 / 2}$

In the Temkin isotherm, B is written instead of RT / $b_{T}$ and equality is expressed by the linearized equation in Eq. (5) (Sharma et al. 2016). If $q_{e}$ is plotted versus $\ln C_{e}$, the $A_{T}$ value is calculated from the slope $B$ of the obtained line and the point at which the line intersects the $q e$ axis. Wherein $B$ is the isotherm constant $(\mathrm{J} / \mathrm{mol})$ associated with the adsorption heat; $A_{T}$, Temkin isotherm constant $(\mathrm{L} / \mathrm{g}) ; b_{T}$, Temkin isotherm constant; $\mathrm{R}$ is the ideal gas constant $(8.314 \mathrm{~J} / \mathrm{mol} \mathrm{K})$, and $\mathrm{T}$ is the absolute temperature $\left({ }^{\circ} \mathrm{K}\right)$.

$q_{e}=B \ln A_{T}+B \ln C_{e}$

In addition, the following equation is used to calculate the removal efficiency in batch adsorption experiments (Argun et al. 2007).

$\%$ Removal $=\left[\left(C_{o}-C_{e}\right) / C_{o}\right] \times 100$ 


\section{Kinetics studies}

To determine the kinetic model, reaction-based models (Lagergren pseudo first-order kinetic model and pseudo second-order kinetic model) and diffusion-based models (Boyd equation and Liquid film diffusion model) were studied. The equations used to calculate the linearized pseudo first-order kinetic model, pseudo second-order kinetic model, Boyd equation and Liquid film diffusion model are given in Eq. (8), (9), (10) and (11), respectively. In addition, the $D_{f}$ equation (Eq. 12) for the film diffusion constant for the liquid film diffusion model is given.

In the calculation of kinetic and diffusion models

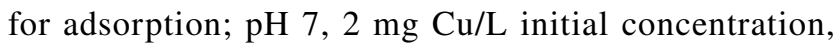
$25^{\circ} \mathrm{C}$ temperature, $300 \mu$ adsorbent size, $5 \mathrm{~g} / \mathrm{L}$ adsorbent dose, $300 \mu$ adsorbent size, $100 \mathrm{rpm}$ mixing speed with $0-5-15-30-60-120$ min working in contact time conditions were studied.

The linearized form of the Lagergren pseudo first-order kinetic model is expressed by the following equation (AlDegs et al. 2006). If $\log \left(q_{e}-q_{t}\right)$ versus $\mathrm{t}$ is plotted, $k_{l} /$ 2.303 is calculated from the slope of the obtained line and $\log q_{e}$ (calculated) from the point where the line intersects the $\log \left(q_{e}-q_{t}\right)$ axis. Here $q_{e}$ denotes adsorption capacity $(\mathrm{mg} / \mathrm{g})$, and $k_{l}$ denotes pseudo first-order kinetic constant.

$\log \left(q_{e}-q_{t}\right)=\log q_{e}-\left(k_{1} / 2.303\right) t$

The linearized form of the pseudo second-order kinetic model is expressed by the following equation (Argun et al. 2007; Celebi et al. 2017b). If $t / q t$ versus $t$ is plotted, $1 /$ $q_{e}$ is calculated from the slope of the obtained line, and $1 /\left(k^{2} q_{e}{ }^{2}\right)$ is calculated from the point at which the line intersects the $t / q_{t}$ axis. So, $q_{e}$ (calculated) is found. Here $q_{e}$ denotes adsorption capacity $(\mathrm{mg} / \mathrm{g})$, and $\mathrm{k}_{2}$ denotes pseudo second-order kinetic constant.

$t / q_{t}=\left[1 /\left(k_{2} q_{e}^{2}\right)\right]+\left(1 / q_{e}\right)$

Boyd equation is expressed by the following equation (Orbak 2009). $B_{b} t$ values calculated from Eq. 8 versus $t$ are plotted. Here, $q_{e}$ denotes the adsorption capacity $(\mathrm{mg} / \mathrm{g}$ ); $q_{t}, t$ is the amount of adsorbed material at the moment; $B_{b}$ indicates the Boyd constant.

$B_{b} t=-0.4977-\ln \left[1-\left(q_{t} / q_{e}\right)\right]$

The film diffusion described by Gupta et al. (2006) is given in Eq. (11). $F$ is the fractional equilibrium expression $\left(F=q_{t} / q_{e}\right), k_{f}$, film diffusion coefficient $\left(\mathrm{m} \mathrm{s}^{-1}\right)$ and $t$ is time (min). It is possible to obtain information about film diffusion from the $\ln (1-F)$ plot plotted versus $t$. In systems controlled by liquid film diffusion, the film diffusion constant $\left(D_{f}\right)$ can be calculated according to Weber and Morris equation (Eq. 12).

$\ln (1-F)=-k_{f} t$

$D_{f}=\left(r_{o} \delta q_{e}\right) / t_{1 / 2}$

$D_{f}$ film diffusion constant $\left(\mathrm{cm}^{2} \mathrm{~s}^{-1}\right), r_{o}$ radius of adsorbent $(\mathrm{cm}), \delta$ film thickness $(\mathrm{cm})$ and $t_{1 / 2}(\mathrm{~min})$ the time taken for half of adsorption to occur. Assuming that the adsorbent has a spherical geometry, film thickness can be taken as $10^{3-} \mathrm{cm}$ according to previous studies.

\section{Thermodynamic studies}

In the calculation thermodynamic parameters of adsorption; $\mathrm{pH} 7,2 \mathrm{mg} / \mathrm{L}$ initial concentration, $5 \mathrm{~g} / \mathrm{L}$ adsorbent dose, $60 \mathrm{~min}$ contact time, $300 \mu$ adsorbent size, $100 \mathrm{rpm}$ mixing speed and at 25,35 and $45^{\circ} \mathrm{C}$ conditions were studied.

Thermodynamic parameters of adsorption can be calculated by Van't Hoff graph drawn by Eq. 14 and Gibbs equation by Eq. 13 (Orbak 2009).

$\Delta G^{o}=\Delta H^{o}-T \Delta S^{o}$

$\ln k_{e}=(\Delta S / R)-(\Delta H / R) 1 / T$

$k_{e}=\left(C_{o}-C_{e}\right) / C_{e}$

By using Eq. 14, Van't Hoff plot is drawn $\ln k_{e}$, versus $1 / T . \Delta H$ is obtained from the slope of the linear line, and $\Delta S$ is obtained from the intercept point.

\section{Characterization studies}

SEM + EDX and XRD analyses that determined topography and morphology of $\mathrm{P}$ natural adsorbent were performed with the service procurement from the BILTEM laboratory of Karamanoglu Mehmet Bey University. For the analysis, "BRUKER D8 Advance with Davinci" XRD device and "HITACHI SU5000" EDX equipped field SEM + EDX device were used. Powdered samples of the $\mathbf{P}$ adsorbent were analyzed.

\section{Results and discussion}

\section{Adsorption equilibrium isotherms}

For $\mathbf{P}$ natural adsorbent; Langmuir, Freundlich, D-R and Temkin isotherms plots are indicated Fig. 2 and according 
Fig. 2 Adsorption equilibrium isotherms: a Langmuir, b Freundlich, $\mathbf{c}$ D-R, d Temkin

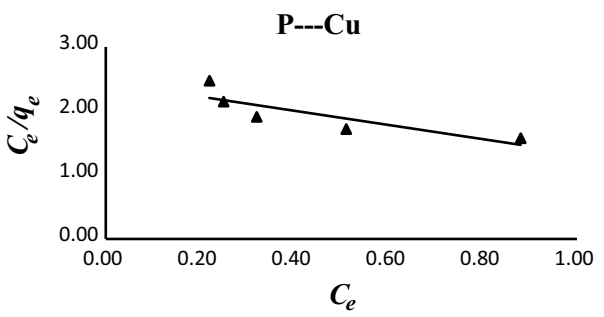

(a)

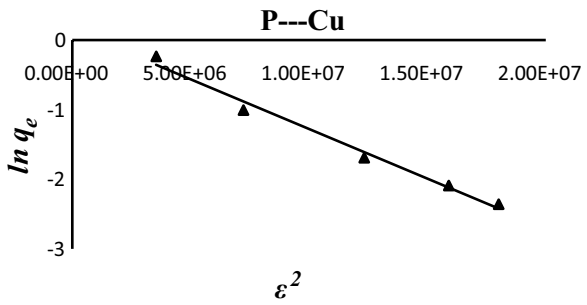

(c)

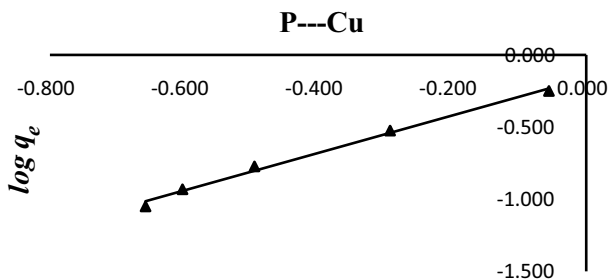

$\log C_{e}$

(b)

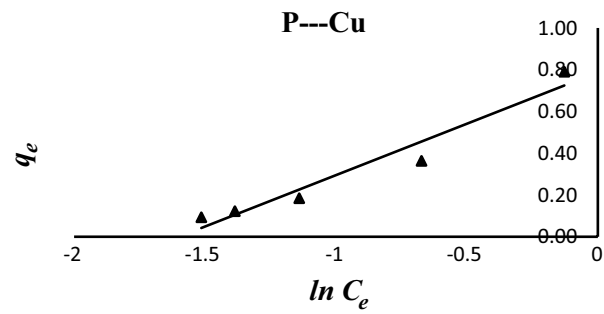

(d)
Table 1 Model data for adsorption isotherms

\begin{tabular}{lll}
\hline İsotherm models & Model data & $\mathrm{Cu}$ \\
\hline Langmuir & $R^{2}$ & 0.7124 \\
& $K(\mathrm{~L} / \mathrm{mg})$ & -0.903 \\
& $b(\mathrm{mg} / \mathrm{g})$ & -0.453 \\
& $R_{L}$ & 10.65 \\
Freundlich & $R^{2}$ & 0.9933 \\
& $K_{f}(\mathrm{mg} / \mathrm{g})$ & 0.6889 \\
& $1 / n$ & 1.2970 \\
& $n$ & 0.77 \\
D-R & $R^{2}$ & 0.9860 \\
& $K^{\prime}$ & $-1.426 \mathrm{E}-07$ \\
$X_{m}^{\prime}(\mathrm{mg} / \mathrm{g})$ & 1.1583 \\
& $E(\mathrm{~kJ} / \mathrm{mol})$ & 1.87 \\
Temkin & $R^{2}$ & 0.9468 \\
& $B(\mathrm{~J} / \mathrm{mol})$ & 0.4916 \\
& $A_{T}$ & 2.1969 \\
& $b_{T}$ & 5039.33 \\
\hline
\end{tabular}

to plots, adsorption isotherms data of models are presented Table 1.

According to isotherm graphs (Fig. 2) and model data (Table 1); $\mathbf{P}$ adsorbent is incompatible with Langmuir model due to its low regression coefficient, negative adsorption capacity and high $R_{L}$ value. In fact, the Langmuir model can be applied to homogeneous and monolayer adsorption systems (Ho 2003) Freundlich, D-R and Temkin models are suitable models with high regression coefficients, and Freundlich model is the most suitable model. Freundlich, D-R and Temkin isotherms are suitable models for heterogeneous and multilayer adsorption systems. This information clearly was showed that $\mathbf{P}$ adsorbent absolutely is not homogeneous.
Although the best fit isotherm is Freundlich, It has $1 / \mathrm{n}$ value above 1. Aziz et al. (2008) was reported that $1 / \mathrm{n}>1$ adsorption bonds were weak, their adsorption capacity decreased and unsuitable. According to the information transferred Jiang et al. (2002); if $\mathrm{n}$ value less than one, adsorption is chemical, otherwise is physical (Wu 2007).

When D-R model data are examined; in the adsorption of pollutant metal $\mathrm{Cu}$ and adsorbent $\mathbf{P}, R^{2}$ value is 0.9860 , and this value is well adapted to experimental data with high regression coefficient. On the other hand, $E$ value is $1.87 \mathrm{~kJ} /$ mol and below $8 \mathrm{~kJ} / \mathrm{mol}$.

Argun et al. (2007) are emphasized that adsorption energy $(E)$, which can be calculated from the D-R isotherm; Physical adsorption below $8 \mathrm{~kJ} / \mathrm{mol}$, ion exchange between 8 and $16 \mathrm{~kJ} / \mathrm{mol}$, particle diffusion predominates in systems with $E>16 \mathrm{~kJ} / \mathrm{mol}$. Adsorption system is physical according to D-R data except kinetics and thermodynamic data. Similar to our study, there are studies reporting physical adsorption as adsorption energy is below $8 \mathrm{~kJ} / \mathrm{mol}: 3.87 \mathrm{~kJ} / \mathrm{mol}$ for modified oak sawdust-Cu (Argun et al. 2007), $0.7 \mathrm{~kJ} / \mathrm{mol}$ for modified brass-Zn (Dada et al. 2012).

Temkin isotherm model also has high regression coefficient $\left(R^{2}=0.9468\right)$. Ignoring extremely low and large concentration values, it assumes that the adsorption heat (function of temperature) of all molecules in the model layer will decrease linearly rather than logarithmic with coverage (Tempkin et al. 1940). The adsorption heat $(B)$ of $\mathbf{P}$ adsorbent for $\mathrm{Cu}$ removal was calculated as $0.4916 \mathrm{~J} / \mathrm{mol}$. This low value of the $B$ indicates physical adsorption. There are some studies in the literature that Temkin isotherm is reported to be the best fit isotherm to experimental data. $\mathrm{Cu}$ (II) removal by rice bran (Wang et al. 2005), Cu, Zn, Cd and $\mathrm{Pb}$ removal by dried Nile rose plant leaves (Abdel-Ghani 
et al. 2007), Al (III) removal by Rhodococcus opacus bacteria (Cayllahua et al. 2010). The most important parameter for this isotherm is the ability to calculate the adsorption heat. However, even the best fit studies have been omitted. $B(\mathrm{~J} / \mathrm{mol})$ is limited in studies. $B$ values $25.34 \mathrm{~J} / \mathrm{mol}$ for phosphoric acid modified rice husk with $\mathrm{Zn}$ (II) removal (Dada et al. 2012) and 0.215, 0.271 and $0.271 \mathrm{~J} / \mathrm{mol}$ removal of Cr (VI) with various agricultural wastes (Sharma et al. 2016) and the researchers stated that there may be physical sorption.

\section{Kinetics and thermodynamic}

In kinetic process design, kinetics, diffusion and their combination can be a speed limiting step.

Therefore, adsorption kinetic models are examined in two main groups as reaction-based models (chemical) and diffusion-based models (mass transport processes) (Ho et al. 2000). The plots for the four different kinetic models examined are shown in Fig. 3, and the calculated kinetic data are given in Table 4. It was examined Lagergren pseudo first-order and pseudo second-order kinetics models as reaction-based models and Boyd equation, Liquid film diffusion model as diffusion-based models.

According to plots (Fig. 3a and b) and kinetics data (Table 2); the most suitable model in terms of regression coefficients is pseudo second-order kinetic model. On account the fact that $R^{2}$ value is closer to 1 . Furthermore, $q_{e}$ (cal) value is closer to $q_{e}$ (exp) value. Thus, pseudo secondorder kinetics model is the best fit model as reaction-based.

If it passes through the line origin, pore diffusion is the process that controls the diffusion rate, and if it does not pass through the origin, film diffusion is the process that controls diffusion rate (Orbak 2009). According to Boyd plot (Fig. 3c); due to the fact that the line does not pass through the origin liquid film diffusion controls process of the diffusion rate and fit model as based diffusion model. Calculated data (Table 2) for the liquid film diffusion model, $k_{f}$ is $0.0226 \mathrm{~ms}^{-1}$, and $D_{f}$ is $1.29 \mathrm{E}-09 \mathrm{~cm}^{2} \mathrm{~s}^{-1}$.

Ho et al. (1999), in their study of the pseudo second-order kinetic model, emphasized that the chemical reaction seems to be important in the speed control step and the pseudo second-order kinetic model fits better with the experimental
Fig. 3 Reaction and diffusionbased models: a pseudo firstorder k.m, b pseudo secondorder k.m, c Boyd equation, $\mathbf{d}$ Liquid film diffusion model

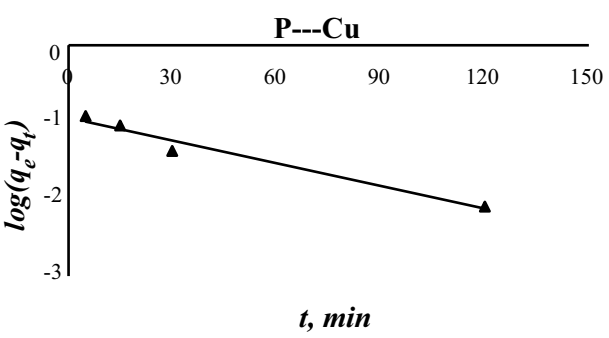

(a)

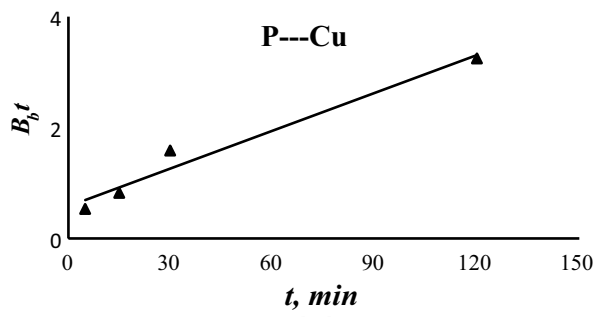

(c)

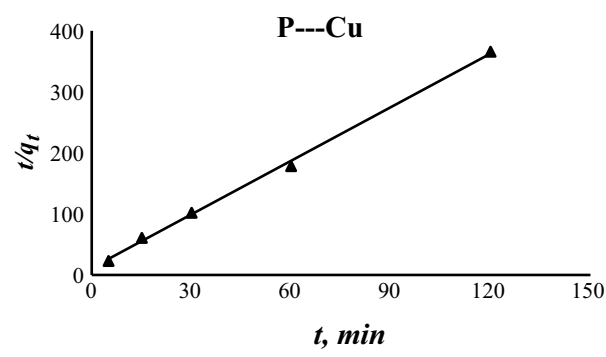

(b)

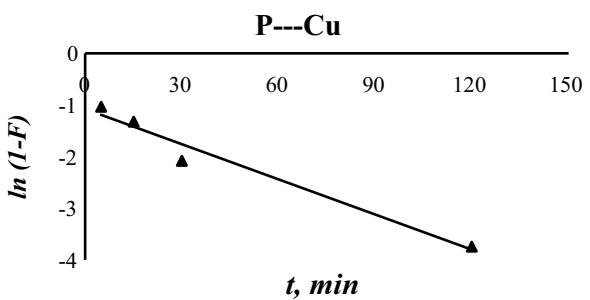

(d)
Table 2 Kinetics model data for $\mathrm{P}-\mathrm{Cu}$ adsorption

\begin{tabular}{lllll}
\hline Pseudo first-order $\mathrm{km}$ & $R^{2}$ & $k_{l}\left(\mathrm{~min}^{-1}\right)$ & $q_{e}(\exp )$ & $q_{e}(\mathrm{cal})$ \\
& 0.9676 & 0.0226 & 0.336 & 0.114 \\
Pseudo second-order $\mathrm{km}$ & $R^{2}$ & $k_{2}(\mathrm{~g} / \mathrm{mg} \min )$ & $q_{e}(\exp )$ & $q_{e}(\mathrm{cal})$ \\
& 0.9982 & 0.7534 & 0.336 & 0.341 \\
Boyd equation & $R^{2}$ & Intercept point & Fit model & \\
Liquid film diffusion & 0.9676 & 0.5792 & Liquid film diffusion & \\
& $R^{2}$ & $K_{f}\left(\mathrm{~m} \mathrm{~s}^{-1}\right)$ & $D_{f}\left(\mathrm{~cm}^{2} \mathrm{~s}^{-1}\right)$ \\
& 0.9676 & 0.0226 & $1.29 \mathrm{E}-09$ & \\
\hline
\end{tabular}




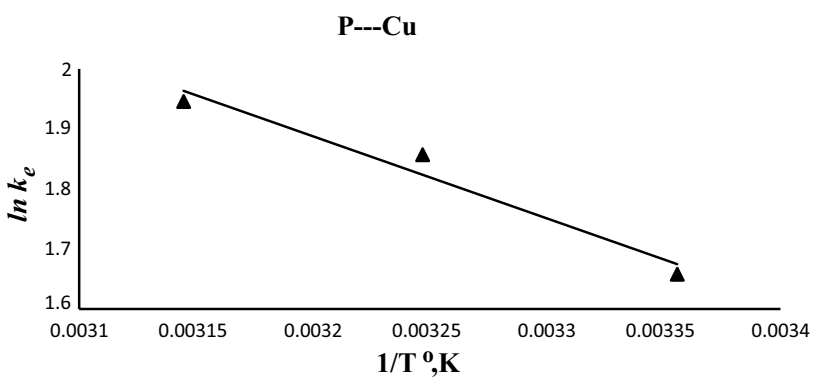

Fig. 4 Van't Hoff plot for P-Cu adsorption system

data. In the previous section according to the results obtained from adsorption isotherms; chemical adsorption findings were obtained only from Freundlich isotherm data, while physical adsorption findings were obtained for D-R and Temkin. According to kinetic data, it may be a chemical adsorption mechanism carried out by pseudo second-order kinetic model. Similarly with our study, Argun et al. (2007), in the study of heavy metal ions removal with modified oak saw dusts, $E$ value obtained from D-R data for all metals and adsorbents obtained results below $8 \mathrm{~kJ} / \mathrm{mol}$. However, they reported conformity to pseudo first- and second-order kinetic models indicating chemical adsorption in the kinetic data. Celebi et al. (2020) studied on adsorption capability of low cost eco-friendly adsorbents in waters containing toxic lead (II), cadmium (II), nickel (II) and zinc (II) heavy metal ions.

Van't Hoff plot was drawn to calculate the thermodynamic data (Fig. 4).

The data obtained from Van't Hoff plot is shown in Table 3.

Thermodynamic analysis of the adsorption process is essential to conclude whether the process is spontaneous or not. The feasibility and spontaneous nature of the adsorption process (Rajamohan et al. 2014).

Table 3 examined; A negative Gibbs free energy change $(\Delta G)$ is an indication that adsorption may spontaneously occur under normal conditions and that the adsorption system may increase due to increasing temperature ( Singh et al. 2006; Argun et al. 2007). In addition that Kyzas et al. (2013), emphasized that the increase in negative values of $\Delta G$ with increasing temperature means that low temperature facilitates adsorption. As can be seen in Table 3, for $\mathrm{P}-\mathrm{Cu}$ adsorption system $\Delta G$ is seen to increase negative values with the increase in temperature.

Enthalpy change $(\Delta H)$ is positive for $\mathrm{P}-\mathrm{Cu}$ adsorption system (Table 4), indicating that the reactions take place endothermically. Smith (1981), emphasized that if enthalpy value is between 2.1 and $20.9 \mathrm{~kJ} / \mathrm{mol}$, physical sorption occurs. When enthalpy value is between 20.9 and $418.4 \mathrm{~kJ} /$ mol, chemical sorption occurs.

Entropy change $(\Delta S)$ is positive for $\mathrm{P}-\mathrm{Cu}$ adsorption system. This indicates an increase in entropy with adsorption according to Ho (2003) and an increase in randomness at the surface of the solid solution. According to the inform transferred from Panday et al. (1985), positive values of $\Delta S$ indicate the interest of adsorbent to metal ion and some changes in adsorbent-adsorbate structure (Aydin et al. 2008). In addition that since the increase in temperature will increase the kinetic energy of a few free molecules, it can be said that the endothermic system contributes to positive entropy (Argun et al. 2007).

\section{Adsorbent characterization}

\section{Chemical composition}

In Table 4, the chemical composition of the oak acorn cap for Quercus robur L. is given. Chemical composition data is cited from Kilic et al. (2010).

According to chemical composition results (Table 4); $\mathbf{P}$ adsorbent contains condensed tannins.

\section{SEM + EDX analysis}

Investigation of the surface structure (topography) of the prepared raw $\mathbf{P}$ adsorbent (P raw) and copper-treated $\mathbf{P}$
Table 3 Thermodynamic data for P-Cu adsorption system

Table 4 Chemical compositions of oak acorn cap $(\mathrm{P})$ adsorbent $(\mathrm{g} / \mathrm{kg} \mathrm{DM})$

\begin{tabular}{llllll}
\hline Ads. Cond & $\mathrm{T},{ }^{\circ} \mathrm{K}$ & $\ln k_{e}$ & $\Delta G(\mathrm{~kJ} / \mathrm{mol})$ & $\Delta H(\mathrm{~kJ} / \mathrm{mol})$ & $\Delta S(\mathrm{~kJ} / \mathrm{mol} \mathrm{K})$ \\
\hline $\mathrm{Cu} \mathrm{C}_{\mathrm{o}}=2 \mathrm{mg} / \mathrm{L}$ & 298 & 1.66 & -4.15 & 11.38 & 0.0520 \\
& 308 & 1.86 & -4.67 & & \\
& 318 & 1.95 & -5.20 & & \\
\hline
\end{tabular}

\begin{tabular}{llllllll}
\hline & DM & CP & EE & Ash & NDF & ADF & CT \\
\hline $\mathrm{P}$ & 930.6 & 28.1 & 4.2 & 29.6 & 681.2 & 539.1 & 17.8 \\
\hline
\end{tabular}

DM: Dry matter, CP Crude protein, EE: Ether extracts, NDF: Neutral detergent fiber, ADF: Acid detergent fiber, CT: Condensed tannin 
adsorbent as named $\mathrm{P}-\mathrm{Cu}(2 \mathrm{mg} \mathrm{Cu} / \mathrm{L}$ initial concentration, 60 min contact time and at $\mathrm{pH}$ 7) and determination of its elemental composition was done by the BILTEM laboratory of Karamanoglu Mehmet Bey University using an SEM device equipped with EDX. P raw and P-Cu analysis results were given by SEM images in Fig. 5 and EDX Fig. 6. EDX that also known EDS, results were calculated with used with APEX ${ }^{\mathrm{TM}}$ software.

As shown in Fig. 5, SEM images of $\mathrm{P}$ raw (Fig. 5a) and P-Cu (Fig. 5b) are different from each other. Hence, the surface topography of $\mathrm{P}$ raw has been changing after copper-treated. While the $\mathrm{P}$ raw microstructure is heterogenous and partially porous, the $\mathrm{P}-\mathrm{Cu}$ microstructure is more homogenous. On the other hand, there are bright areas locally on the P-Cu surface. Wan Ngah et al. (2012) stated that the bright areas in the SEM image seen after adsorption indicate the presence of copper.

Figure 6 is shown the EDX spectrums and results with SEM images of full scanning different areas. According to EDX analysis results (Fig. 6a and b) that were taken different areas of $\mathrm{P}$ raw adsorbent, the elemental compositions were different. The fellow elements were determined in both areas
Fig. 5 SEM images of $P$ raw and $\mathrm{P}-\mathrm{Cu}$ adsorbent: a $\mathrm{P}$ raw, $\times 2500,20 \mu \mathrm{m} ; \mathbf{b}$ $\mathrm{P}-\mathrm{Cu}, \times 2500,20 \mu \mathrm{m}$
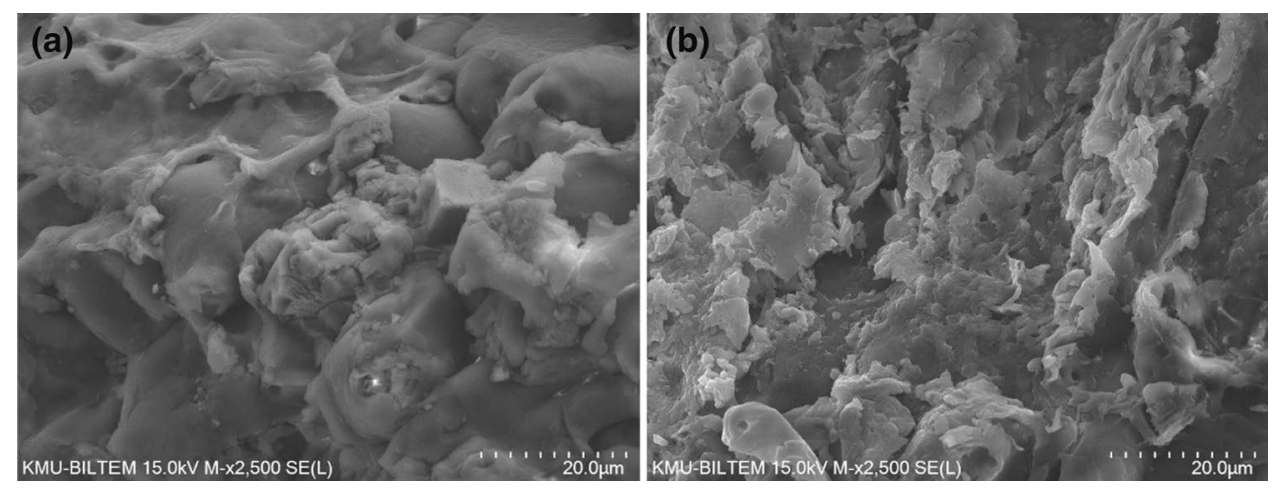

Fig. 6 EDX spectrum of P raw: a Area 321 , b Area 322

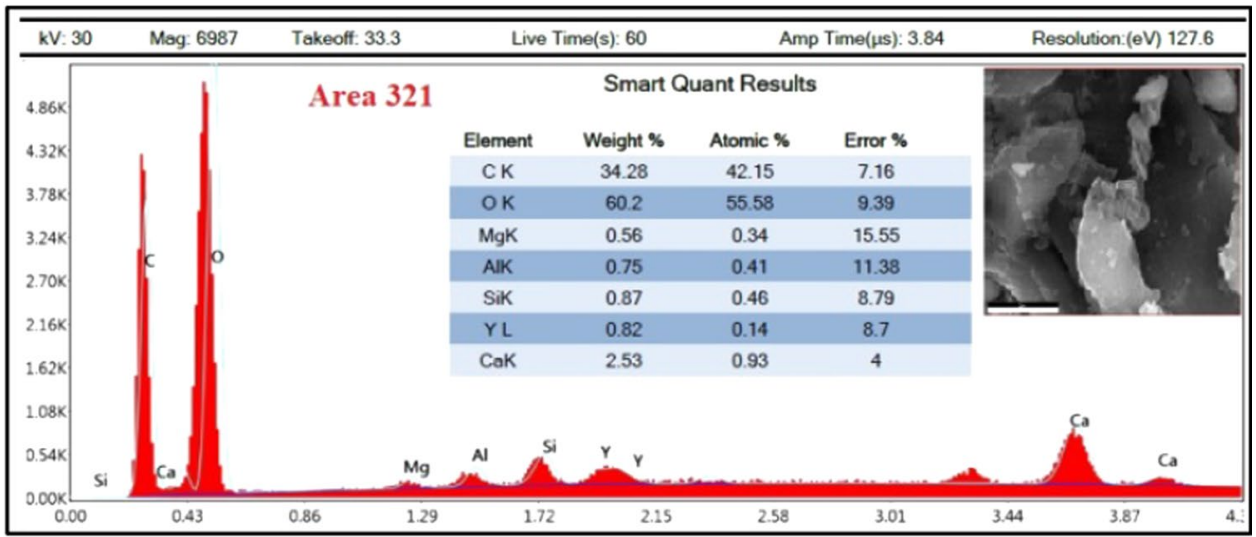

(a)

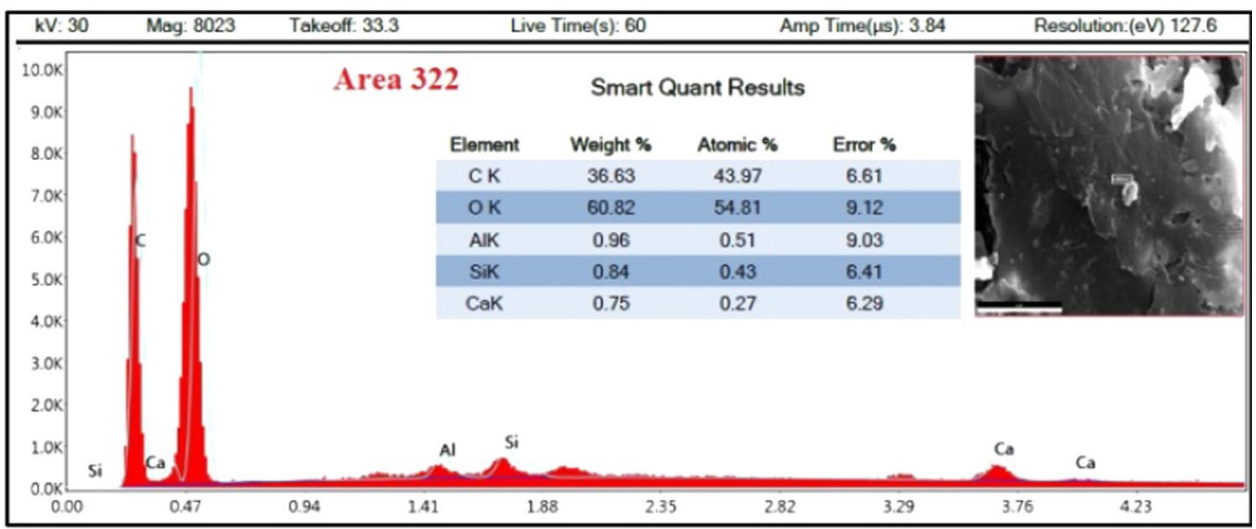

(b) 
$\mathrm{C}, \mathrm{O}, \mathrm{Al}, \mathrm{Si}$ and $\mathrm{Ca} . \mathrm{Mg}$ and $\mathrm{Y}$ elements were determined in only Area 322. Most of the P raw adsorbent structure as weight percentage are composed of carbon and oxygen.

\section{XRD analysis}

To learn about the structural features of the $\mathbf{P}$ adsorbent, XRD analysis of $\mathrm{P}$ raw and $\mathrm{P}-\mathrm{Cu}$ were done by the BILTEM laboratory of Karamanoglu Mehmet Bey University using an XRD device. $\mathrm{P}$ raw and $\mathrm{P}-\mathrm{Cu}$ analysis results were given by XRD patterns in Fig. 7.

Since the $\mathbf{P}$ adsorbent is in organic structure, it has been seen that very complex peaks are formed due to high carbon and oxygen. Therefore, when XRD patterns were examined; there were changes in the peak structure of the raw $\mathbf{P}$ adsorbent after adsorption with $\mathrm{Cu}$. (Fig. 7a and b). The XRD data were obtained by graphite-monochromated $\mathrm{Cu} / \mathrm{K} \alpha$ radiation $(\lambda=1.54060 \AA)$. The XRD spectrums were drawn by DIFFRAC.EVA 4.1.1 software.

It was observed a deterioration in the structure of the peak in raw $\mathrm{P}$ at $2 \theta=23.6$ and 14.3 degrees, whereas peak length has grown at $2 \theta=37.5$ degree. However, it was observed some peaks occurred after adsorption with $\mathrm{Cu}$. $\mathrm{Cu}, \mathrm{CuO}$ and $\mathrm{Cu}_{2} \mathrm{O}$ were determined by using MATCH Version 2 software. The peaks found were in $2 \theta$ degree: $\mathrm{Cu}$ : 36 and 42, $\mathrm{CuO}: 66.4,67.3$ and $\mathrm{Cu}_{2} \mathrm{O}: 36.5,77.4$. The $2 \theta$ peak degree results determined for copper $(\mathrm{Cu})$ and copper compounds $\left(\mathrm{CuO}, \mathrm{Cu}_{2} \mathrm{O}\right)$ are very close to the peak degree results reported by Collins et al. (2012). Especially, $2 \theta$ degree 66.4 peak was the most obvious peak among the newly formed peaks. Thus, $\mathrm{Cu}^{+2}$ ions were retained the $\mathbf{P}$ adsorbent surface.

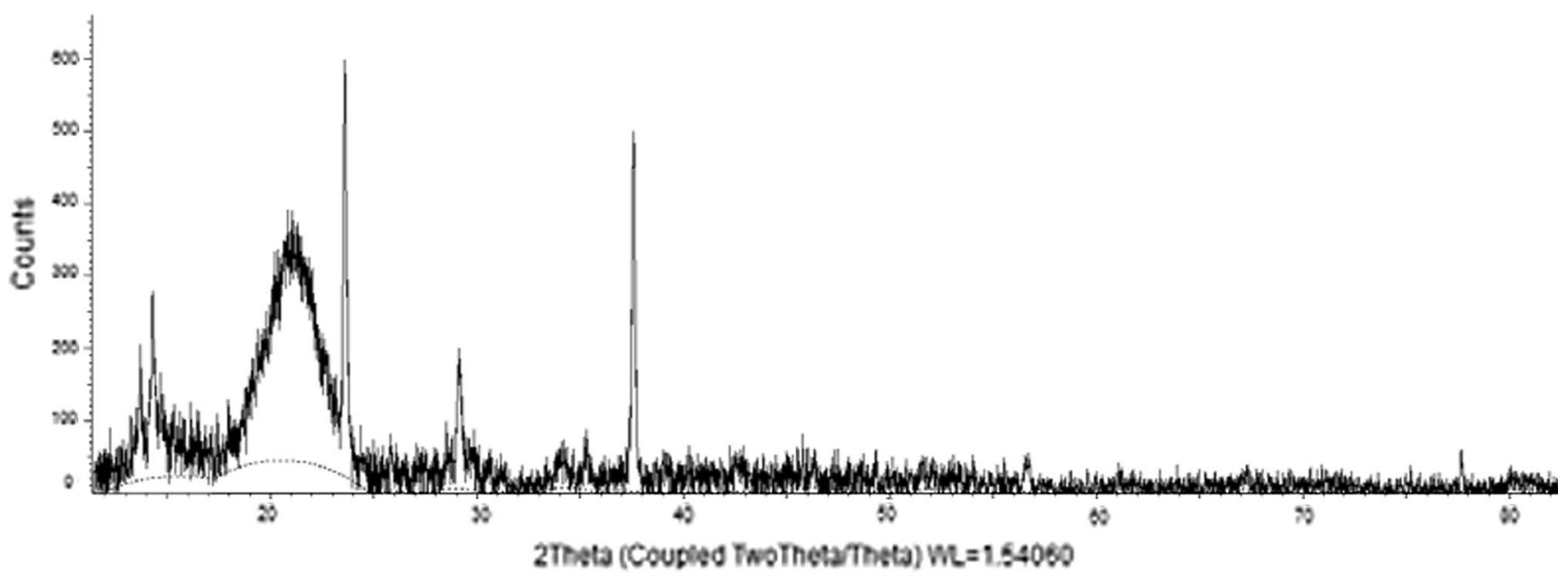

(a)

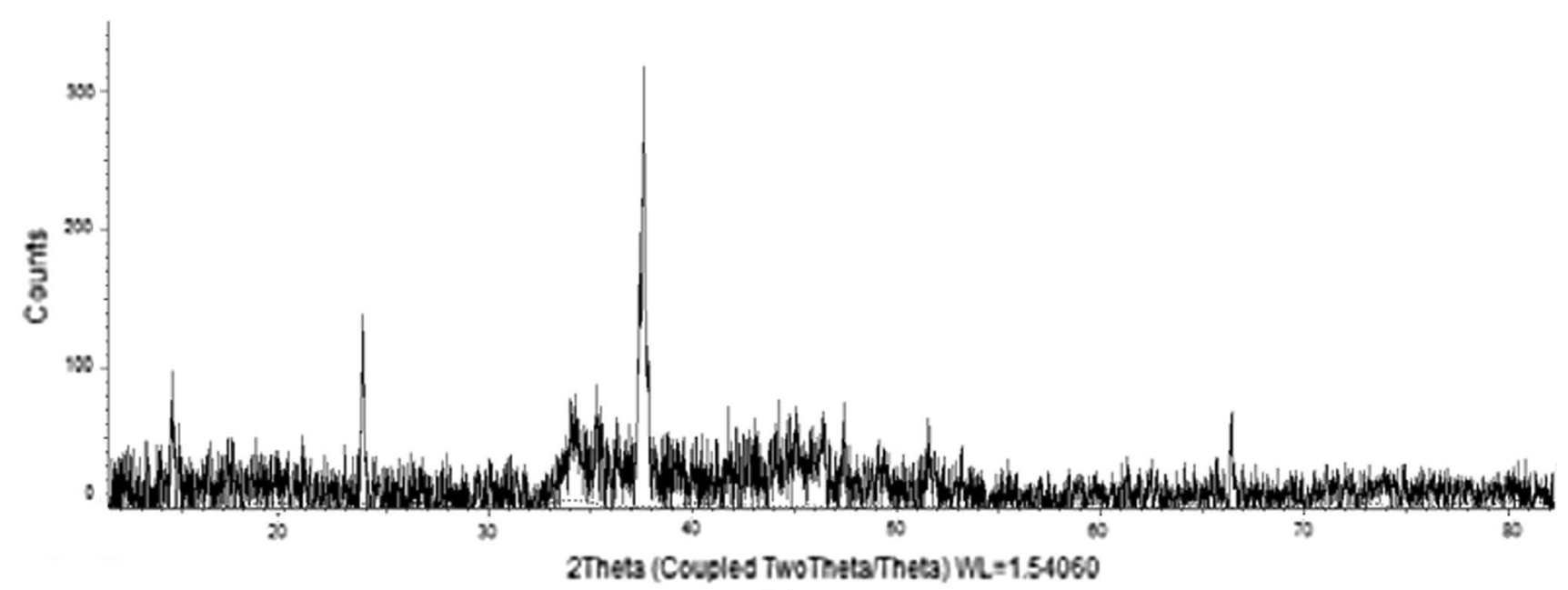

(b)

Fig. 7 XRD patterns of $\mathrm{P}$ raw and $\mathrm{P}-\mathrm{Cu}$ : a $\mathrm{P}$ raw, $\mathbf{b} \mathrm{P}-\mathrm{Cu}$ 
According to these results, although not certain $\mathrm{Cu}, \mathrm{Cu}$ +1 and $\mathrm{Cu}^{+2}$ ions in the solution with the adsorbent surface $\mathrm{CuO}$ and $\mathrm{Cu}_{2} \mathrm{O}$ formed as a compound and also in the elementary state as $\mathrm{Cu}$ was held on the surface.

\section{Tannins effect}

Tannins (commonly referred to as tannic acid) are watersoluble polyphenols that are present in many plant foods. The antimicrobial activities of tannins are well documented. The growth of many fungi, yeasts, bacteria and viruses was inhibited by tannins. Also, form chelates with metal ions (Chung et al. 1998). Akiyama et al. (2001) was emphasized that tannins have an inhibitory effect against bacteria that can be found in water, such as Escherichia coli, Staphylococcus aureus, Clostridium perfringens.

The polyphenolic compounds in different regions (e.g., bark, leaf) in Quercus (oak) species have been classified as flavonoids, condensed tannins and hydrolyzable tannins in studies by Şöhretoğlu et al. (2004). Celebi (2020b) has aimed to evaluate experimental results on the behavior of various tea wastes for removal of $\mathrm{Cr}^{6+}$ under internal, and removal for $\mathrm{Cr}^{6+}$ efficiency was achieved under optimum experimental conditions as $88 \%$.

There are also studies on the use of tannins in water treatment by adsorption. Anirudhan et al. (2008) are expressed that metal cations in the $\mathrm{pH} 3-6$ range, are adsorbed by cation exchange mechanism by releasing protons from phenolic $\mathrm{OH}$ groups found in tannin-containing hydrotalcite adsorbent structure. Şengil et al. (2009) have made a removal of $\mathrm{Cu}$ (II) with Valonia residues, which is a type of acorn oak. They were determined that the copper ions are retained by pyrogallol groups in the tannin with ion exchange and complexation.

Kuppusamy et al. (2016) in the removal studies of Cr (VI) using oak (Quercus robur) acorn peel; reported that chromium is retained on the adsorbent surface by reduction and the polyphenols in the adsorbent structure serve as reducing agents. Badawi et al. (2017), in their $\mathrm{Al}$ and $\mathrm{Pb}$ removal studies with chitosan modified with tannic acid; the tannic acid molecules may contain a plurality of polarizable phenolic hydroxyl groups, some of which are positively charged and others negatively charged; stated that metals are removed by interactions between these groups and metal ions. The acorn cap $(\mathrm{P})$ adsorbent in this study has organic structure and is known to contain condensed tannin (Table 4). XRD pattern that obtained in the adsorbent characterization studies is given in Fig. 7a and Fig. 7b.

Anirudhan et al. (2008) have carried out a $\mathrm{Cu}, \mathrm{Zn}$ and Cd removal study with tannin doped hydrotalcite adsorbent (TA-HTC). They emphasized that the peak seen in TA-HTC's XRD pattern at $2 \theta=30^{\circ}$ verified the presence of tannin molecule. This information is very valuable for our study. Owing to the fact that there is a peak at approximately $2 \theta=30^{\circ}$ in the XRD pattern of the raw $\mathrm{P}$ (acorn cap) adsorbent (Fig. 7a). After the adsorption of raw $\mathbf{P}$ adsorbent with $\mathrm{Cu}$, it is seen that the size of the peak is considerably reduced or lost (Fig. 7b).

To sum up, the most valuable result to be drawn here is that the polyphenolic groups in the structure of tannins are the main factors in the retention of $\mathbf{C u}$ metal in the $\mathbf{P}$ adsorbent. It has been thought that the effective mechanisms are ion exchange, complexation and interaction between ions.

\section{Conclusions}

In this paper, it was investigated $\mathrm{Cu}$ metal adsorption mechanisms with adsorption equilibrium isotherms, kinetics, thermodynamic and characterization studies using non-modified acorn caps which obtained by Quercus robur L. at low initial copper concentrations in copper removal from waters. In this manner, low cost adsorbent was prepared, and the more favorable results were procured which could be evaluated within the framework of water recommendations and legal regulations.

It was found the most fit model Freundlich model. D-R and Temkin was found as suitable models. Thus, $\mathbf{P}$ adsorbent is certainly not homogeneus, and adsorption is multilayered. According to calculated from D-R adsorption isotherm; $E$ value $1.87 \mathrm{~kJ} / \mathrm{mol}$ and below $8 \mathrm{~kJ} /$ mol. Therefore, it indicates that physical adsorption takes place. Pseudo second-order kinetics model as reactionbased model and liquid film diffusion model as diffusionbased model was determined the most fit models in the kinetics studies. Negative Gibbs free energy change $(\Delta G)$ values indicate that adsorption may spontaneously occur under normal conditions and that adsorption demand may increase due to increased temperature. The enthalpy change $(\Delta H)$ was calculated to be $11.38 \mathrm{~kJ} / \mathrm{mol}$, and a positive value of $\Delta H$ indicates an endothermic reaction. The entropy change $(\Delta S)$ was calculated $0.0520 \mathrm{~kJ} / \mathrm{mol} \mathrm{K}$, and a positive value of $\Delta S$ indicates an increase in entropy with adsorption and increased randomness at the surface of the solid - solution.

$\mathrm{SEM}+\mathrm{EDX}$ and XRD were applied for $\mathrm{P}$ raw and $\mathrm{P}-\mathrm{Cu}$ adsorbent characterizations. According to characterization results, $\mathbf{P}$ adsorbent structure was heterogeneous, and $\mathrm{Cu}$ was retained adsorbent surface. SEM image and XRD pattern of the $\mathbf{P}$ adsorbent were changed after adsorption by $\mathrm{Cu}$. In addition that, $\mathrm{Cu}$ was retained elemental $(\mathrm{Cu})$ and compounds $\left(\mathrm{CuO}\right.$ and $\left.\mathrm{Cu}_{2} \mathrm{O}\right)$.Tannins of the $\mathbf{P}$ adsorbent structure were affected adsorption mechanisms with ion exchange, complexation and interactions between ions.

In the experiments, it was seen that $84 \%$ removal efficiency and $0.336 \mathrm{mg} / \mathrm{g}$ adsorption capacity was achieved

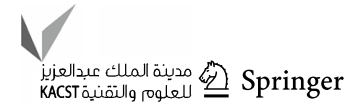


with the $\mathbf{P}$ adsorbent in optimum conditions ( $\mathrm{pH} \mathrm{7,2} \mathrm{mg}$ $\mathrm{Cu} / \mathrm{L}$ initial concentration, $25^{\circ} \mathrm{C}$ temperature, $300 \mu$ adsorbent size, $5 \mathrm{~g} / \mathrm{L}$ adsorbent dose, $300 \mu$ adsorbent size, $100 \mathrm{rpm}$ mixing speed and $60 \mathrm{~min}$ contact time). Therefore, the $\mathrm{P}$ adsorbent is more economical than many adsorbents used or recommended. Hence it does not include costs such as modification, regeneration and hazardous waste disposal costs. In addition, Quercus robur used in the preparation of the adsorbent is a common species all over the world. It can also be used for various purposes after removal. It can be used for agricultural purposes for micronutrient needs of plants from low $\mathrm{Cu}$ concentrations in the adsorbent. On the other hand, used adsorbents can be reused to remove turbidity, precipitate and, to remove some special contaminants (such as phosphorus) due to tannins in their structure.

The outstanding advantages of this study are its non-modified preparation, acceptable removal efficiency, reusability for other purposes after use and proving the role of tannins in adsorbent removal efficiency.

These findings suggested that the effectiveness of $\mathbf{P}$ adsorbent should be tested in real water samples in the removal of copper and other metals by adsorption and the matrix effects that caused by other ions should be examined in future studies. In fact, its effects on disinfection can be examined microbiologically.

It could be concluded that non - modified $\mathbf{P}$ adsorbent is a natural adsorbent that can be classified among the LCAs and eco-friendly, for copper removal in water by the adsorption.

Acknowledgements The authors present their satisfaction to the BILTEM laboratory of Karamanoğlu Mehmet Bey University for their contribution to the SEM, EDX and XRD studies for this research, in which was obtained from a part of Zafer ZEYBEK's Ph.D. Thesis.

Funding The studies were made entirely by the authors' own means, and no financial support was provided from any institution or organization for this manuscript.

\section{Declarations}

Conflict of interest The authors declare that there is no conflict of interest that is relevant to the content of this article. The authors have made significant contributions at the various stages of the preparation of this manuscript and have agreed on its publication in this journal.

Open Access This article is licensed under a Creative Commons Attribution 4.0 International License, which permits use, sharing, adaptation, distribution and reproduction in any medium or format, as long as you give appropriate credit to the original author(s) and the source, provide a link to the Creative Commons licence, and indicate if changes were made. The images or other third party material in this article are included in the article's Creative Commons licence, unless indicated otherwise in a credit line to the material. If material is not included in the article's Creative Commons licence and your intended use is not permitted by statutory regulation or exceeds the permitted use, you will need to obtain permission directly from the copyright holder. To view a copy of this licence, visit http://creativecommons.org/licenses/by/4.0/.

\section{References}

Abdel-Ghani N, Elchaghaby G (2007) Influence of operating conditions on the removal of $\mathrm{Cu}, \mathrm{Zn}, \mathrm{Cd}$ and $\mathrm{Pb}$ ions from wastewater by adsorption. Int J Environ Sci Technol 4:451-456

Abdić Š, Memić M, Šabanović E, Sulejmanović J, Begić S (2018) Adsorptive removal of eight heavy metals from aqueous solution by unmodified and modified agricultural waste tangerine peel. Inter J environ sci technol 15:2511-2518

Acar FN, Eren Z (2006) Removal of $\mathrm{Cu}(\mathrm{II})$ ions by activated poplar sawdust (Samsun Clone) from aqueous solutions J Hazard Mater. 137:909-914 doi:https://doi.org/10.1016/j.jhazmat.2006.03.014

Afroze S, Sen TK (2018) A Review on Heavy Metal Ions and Dye Adsorption from Water by Agricultural Solid Waste Adsorbents Water. Air Soil Pollut. https://doi.org/10.1007/s11270-018-3869-z

Akiyama H, Fujii K, Yamasaki O, Oono T, Iwatsuki K (2001) Antibacterial action of several tannins against Staphylococcus aureus. J Antimicrob Chemother 48:487-491. https://doi.org/10.1093/jac/ 48.4.487

Akkaya G, Güzel F (2013) Bioremoval and recovery of $\mathrm{Cu}(\mathrm{II})$ and $\mathrm{Pb}$ (II) from aqueous solution by a novel biosorbent watermelon (Citrullus lanatus) seed hulls: Kinetic study, equilibrium isotherm. SEM FTIR Anal Desalination W Treat 51:7311-7322. https://doi. org/10.1080/19443994.2013.815685

Al-Degs YS, El-Barghouthi MI, Issa AA, Khraisheh MA, Walker GM (2006) Sorption of $\mathrm{Zn}(\mathrm{II}), \mathrm{Pb}(\mathrm{II})$ and $\mathrm{Co}(\mathrm{II})$ using natural sorbents: Equilibrium and kinetic studies. Water Res. 40:2645-2658

Al-Saydeh SA, El-Naas MH, Zaidi SJ (2017) Copper removal from industrial wastewater: A comprehensive review. J Ind Eng Chem. 56:35-44

Al-Shannag M, Al-Qodah Z, Bani-Melhem K, Qtaishat MR, Alkasrawi M (2015) Heavy metal ions removal from metal plating wastewater using electrocoagulation: Kinetic study and process performance. Chem Eng J 260:749-756. https://doi.org/10.1016/j. cej.2014.09.035

Albadarin AB, Moa J, Glocheux Y, Allen S, Walker G, Mangwandi C (2014) Preliminary investigation of mixed adsorbents for the removal of copper and methylene blue from aqueous solutions. Chem Eng J 255:525-534. https://doi.org/10.1016/j.cej.2014.06. 029

Anirudhan TS, Suchithra PS (2008) Synthesis and characterization of tannin-immobilized hydrotalcite as a potential adsorbent of heavy metal ions in effluent treatments. Appl Clay Sci 42:214-223

Anonymous (2017) Copper USEPA Bicinchoninate Method (Method $8506 \mathrm{CuVer} 1), 11$ edn. Hach Company/Hach Lange GmbH,

Aranda-García E, Morales-Barrera L, Pineda-Camacho G, CristianiUrbina E (2014) Effect of pH, ionic strength and background electrolytes on $\mathrm{Cr}(\mathrm{VI})$ and total chromium removal by acorn shell of Quercus crassipes Humb \& Bonpl. Environ Monit Assess 186:6207-6221

Argun ME, Dursun S (2008) A new approach to modification of natural adsorbent for heavy metal adsorption. Bioresour Technol 99:2516-2527. https://doi.org/10.1016/j.biortech.2007.04.037

Argun ME, Dursun S, Karatas M (2009) Removal of Cd(II), Pb(II), $\mathrm{Cu}(\mathrm{II})$ and $\mathrm{Ni}(\mathrm{II})$ from water using modified pine bark Desalination 249:519-527 doi:https://doi.org/10.1016/j.desal.2009.01.020

Argun ME, Dursun S, Ozdemir C, Karatas M (2007) Heavy metal adsorption by modified oak sawdust: thermodynamics and kinetics. J Hazard Mater 141:77-85. https://doi.org/10.1016/j.jhazm at.2006.06.095

Ashwini A, Udayasimha L, Vyshnavi DR, Usha HS (2018) Comparative study on removal of copper from aqueous solution by modified and non modified sawdust adsorption. Inter J P Appl Math 120:6709-6725 
Aydin H, Bulut Y, Yerlikaya C (2008) Removal of copper (II) from aqueous solution by adsorption onto low-cost adsorbents. J Environ Manage. 87:37-45

Azhdarpoor A, Hoseini R, Dehghani M (2015) Leaching Zn, Cd, Pb and $\mathrm{Cu}$ from wastewater sludge using Fenton process. J Health Sci Surveill Sys 3:153-159

Aziz HA, Adlan MN, Ariffin KS (2008) Heavy metals (Cd, Pb, Zn, Ni, $\mathrm{Cu}$ and $\mathrm{Cr}(\mathrm{III})$ ) removal from water in Malaysia: Post treatment by high quality limestone. Bioresour Technol. 99:1578-1583

Badawi M, Negm N, Kana MA, Hefni H, Moneem MA (2017) Adsorption of aluminum and lead from wastewater by chitosan-tannic acid modified biopolymers: isotherms, kinetics, thermodynamics and process mechanism. Inter J Biol Macromol. 99:465-476

Bayat B (2002) Comparative study of adsorption properties of Turkish fly ashes: I. The case of nickel(II), copper(II) and zinc(II). J Hazard Mater 95:251-273 doi:https://doi.org/10.1016/S03043894(02)00140-1

Berraksu N, Ayan EM, Yanik J (2012) Use of forestry wastes for biosorption of dyes and Cr (VI) J Chem 2013

Bhattacharyya KG, Gupta SS (2011) Removal of Cu(II) by natural and acid-activated clays: An insight of adsorption isotherm, kinetic and thermodynamics Desalination 272:66-75 doi:https://doi.org/ 10.1016/j.desal.2011.01.001

Bilal M et al. (2013) Waste biomass adsorbents for copper removal from industrial wastewater--a review. J Hazard Mater $263 \mathrm{Pt}$ 2:322-333 doi:https://doi.org/10.1016/j.jhazmat.2013.07.071

Bojic AL, Bojic D andjelkovic T (2009) Removal of Cu2+ and Zn2+ from model wastewaters by spontaneous reduction-coagulation process in flow conditions. J Hazard Mater 168:813-819 doi:https://doi.org/10.1016/j.jhazmat.2009.02.096

Bondy SC, Campbell A (2018) Water quality and brain function. Inter J Environ Res Publ Health 15 doi:https://doi.org/10.3390/ijerp h15010002

Brewer GJ (2012) Copper toxicity in Alzheimer's disease: cognitive loss from ingestion of inorganic copper. J Trace Elem Med Biol 26:89-92. https://doi.org/10.1016/j.jtemb.2012.04.019

Caprarescu S, Purcar V, Sarbu A, Radu A-L, Ghiurea M, Maior I (2014) The use of electrodialysis for $\mathrm{Cu} 2+$ removal from wastewater Revue Roumaine de Chimie 59

Cayllahua JEB, Torem ML (2010) Biosorption of aluminum ions onto Rhodococcus opacus from wastewaters. Chem Eng J 161:1-8. https://doi.org/10.1016/j.cej.2010.03.025

Celebi H (2020a) Boron Adsorption Capacity of Natural Pumpkin Seed Shell. BEU J Sci 9(4):1698-1710

Celebi H (2020b) Recovery of detox tea wastes: Usage as a lignocellulosic adsorbent in Cr6+ adsorption. J Environ Chem Eng 5(3): 104310

Celebi H, Gök G, Gök O (2020) Adsorption capability of brewed tea waste in waters containing toxic lead (II), cadmium (II), nickel (II) and zinc (II) heavy metal ions. Sci Rep 10:17570

Celebi H, Gök O (2017a) Use of AQIS for adsorption of $\mathrm{Pb}$ from aqueous solution. SIgma J Eng \& Nat Sci 35(1):69-75

Celebi H, Gök O (2017b) Evaluation of lead adsorption kinetics and isotherms from aqueous solution using natural walnut shell. Inter J Environ Res 11(1):83-90

Chakravarty S, Pimple S, Chaturvedi HT, Singh S, Gupta KK (2008) Removal of copper from aqueous solution using newspaper pulp as an adsorbent. J Hazard Mater 159:396-403. https://doi.org/10. 1016/j.jhazmat.2008.02.030

Chung K-T, Wong TY, Wei C-I, Huang Y-W, Lin Y (1998) Tannins and human health: a review. Crit Rev Food Sci Nutr 38:421-464

Collins D, Luxton T, Kumar N, Shah S, Walker VK, Shah V (2012) Assessing the impact of copper and zinc oxide nanoparticles on soil: a field study. PLoS ONE 7:e42663
Crini G, Lichtfouse E, Wilson LD, Morin-Crini N (2019) Conventional and non-conventional adsorbents for wastewater treatment. Environ Chem Lett 17:195-213

Dada A, Olalekan A, Olatunya A, Dada O (2012) Langmuir, Freundlich, Temkin and Dubinin-Radushkevich isotherms studies of equilibrium sorption of $\mathrm{Zn} 2+$ unto phosphoric acid modified rice husk IOSR. J Appl Chem 3:38-45

De Gisi S, Lofrano G, Grassi M, Notarnicola M (2016) Characteristics and adsorption capacities of low-cost sorbents for wastewater treatment: a review Sustainable. Mater Technol 9:10-40

Dursun S, Argun ME, Celik N, Celebi F (2011) Copper (II) removal from water by natural zeolites. Environ Earth Sci. 831-840 doi:https://doi.org/10.1007/978-3-540-95991-5-78

Gautam RK, Sharma SK, Mahiya S, Chattopadhyaya MC (2015) CHAPTER 1 Contamination of Heavy Metals in Aquatic Media: Transport, Toxicity and Technologies for Remediation. In: Heavy Metals In Water: Presence, Removal and Safety. Royal Soc Chem. pp 1-24. doi:https://doi.org/10.1039/9781782620 174-00001

Gupta SS, Bhattacharyya KG (2006) Adsorption of Ni (II) on clays. J Coll Interface Sci 295:21-32

Heidmann I, Calmano W (2008) Removal of Zn(II), Cu(II), Ni(II), $\mathrm{Ag}(\mathrm{I})$ and $\mathrm{Cr}(\mathrm{VI})$ present in aqueous solutions by aluminium electrocoagulation. J Hazard Mater 152:934-941 doi:https://doi. org/10.1016/j.jhazmat.2007.07.068

Ho Y-S (2003) Removal of copper ions from aqueous solution by tree fern. Water Res 37:2323-2330. https://doi.org/10.1016/ S0043-1354(03)00002-2

Ho YS, McKay G (1999) Pseudo-second order model for sorption processes. Process Biochem 34:451-465. https://doi.org/10. 1016/S0032-9592(98)00112-5

Ho YS, Ng JCY, McKay G (2000) KINETICS OF POLLUTANT SORPTION BY BIOSORBENTS: REVIEW. Sep Purif Methods 29:189-232. https://doi.org/10.1081/SPM-100100009

Iakovleva E, Sillanpää M (2013) The use of low-cost adsorbents for wastewater purification in mining industries. Environ Sci Pollut Res 20:7878-7899. https://doi.org/10.1007/s11356-013-1546-8

Jiang J-Q, Cooper C, Ouki S (2002) Comparison of modified montmorillonite adsorbents. Part I: preparation, characterization and phenol adsorption. Chemosphere 47:711-716

Kehinde OO, Oluwatoyin TA, Aderonke OO (2009) Comparative analysis of the efficiencies of two low cost adsorbents in the removal of $\mathrm{Cr}$ (VI) and $\mathrm{Ni}$ (II) from aqueous solution African. J Environ Sci Tech. 3

Khan MA, Rao RAK, Ajmal M (2008) Heavy metal pollution and its control through nonconventional adsorbents (1998-2007): a review. J Int Environ Appl Sci. 3:101-141

Kilic U, Boga M, Guven I (2010) Chemical Composition and Nutritive Value of Oak(Quercus robur)Nut and Leaves. J Appl Anim Res. 38:101-104 doi:https://doi.org/10.1080/09712119.2010. 9707165

Krstić V, Urošević T, Pešovski B (2018) A review on adsorbents for treatment of water and wastewaters containing copper ions. Chem Eng Sci 192:273-287. https://doi.org/10.1016/j.ces.2018. 07.022

Kumari AR, Sobha K (2015) Cost effective and eco-friendly method for copper removal by adsorption with Emu feather (Dromaius novaehollandiae) and Chitosan (Agaricus bisporus) Composite. Int J Chem Tech Res. 8:1769-1782

Kuppusamy S, Thavamani P, Megharaj M, Venkateswarlu K, Lee YB, Naidu R (2016) Oak (Quercus robur) Acorn Peel as a Low-Cost Adsorbent for Hexavalent Chromium Removal from Aquatic Ecosystems and Industrial Effluents Water. Air, \& Soil Poll 227:62. https://doi.org/10.1007/s11270-016-2760-z

Kuppusamy S, Venkateswarlu K, Thavamani P, Lee YB, Naidu R, Megharaj M (2017) Quercus robur acorn peel as a novel

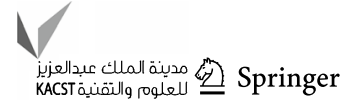


coagulating adsorbent for cationic dye removal from aquatic ecosystems. Ecol Eng 101:3-8. https://doi.org/10.1016/j.ecoleng. 2017.01.014

Kyzas GZ, Kostoglou M (2014) Green Adsorbents for Wastewaters: A Critical Review. Mater (Basel). 7:333-364

Kyzas GZ, Travlou NA, Kalogirou O, Deliyanni EA (2013) Magnetic Graphene Oxide: Effect of Preparation Route on Reactive Black 5 Adsorption. Mater (Basel). 6:1360-1376. https://doi.org/10.3390/ ma6041360

Lee Y, Park TG (2011) Facile fabrication of branched gold nanoparticles by reductive hydroxyphenol derivatives. Langmuir 27:2965-2971

Oguz TC (2015) Proposed solutions for common problems of water quality and treatment in drinking water treatment. Expertise Thesis, Ministry of Forestry and Water Affairs

Orbak İ (2009) Removal Of Envıronmental Pollutants By Usıng Actıvated Carbon. PhD Thesis, İstanbul Technical University

Ozcan S, Celebi H, Ozcan Z (2018) Removal of heavy metals from simulated water by using eggshell powder. Desalin Water Treat 127:75-82

Panday KK, Prasad G, Singh V (1985) Copper(II) removal from aqueous solutions by fly ash. Water Res 19(7):869-873. https://doi.org/ 10.1016/0043-1354(85)90145-9

Rajamohan N, Rajasimman M, Rajeshkannan R, Saravanan V (2014) Equilibrium, kinetic and thermodynamic studies on the removal of Aluminum by modified Eucalyptus camaldulensis barks. Alexandria Eng J. 53:409-415

Ravikumar S, Yoo I-k, Lee SY, Hong SH (2011) Construction of Copper Removing Bacteria Through the Integration of Two-Component System and Cell Surface Display. Appli Biochem Biotechnol 165:1674-1681

Şengil İA, Özacar M, Türkmenler H (2009) Kinetic and isotherm studies of $\mathrm{Cu}$ (II) biosorption onto valonia tannin resin. J Hazard Mater. 162:1046-1052 doi:https://doi.org/10.1016/j.jhazmat. 2008.05.160

Sharma PK, Ayub S, Tripathi CN (2016) Isotherms describing physical adsorption of $\mathrm{Cr}$ (VI) from aqueous solution using various agricultural wastes as adsorbents Cogent Engineering 3:1186857

Singh TS, Parikh B, Pant K (2006) Investigation on the sorption of aluminium in drinking water by low-cost adsorbents. Water SA 32:49-54

Smith JM (1981) Chemical Engineering Kinetics. McGrawHill, New York
Şöhretoğlu D, Sakar MK (2004) Polyphenolic constituents and biological activities of Quercus species J Fac Pharm. Ankara 33:183-215

Tempkin M, Pyzhev V (1940) Kinetics of ammonia synthesis on promoted iron. Catalyst Acta Phys Chim USSR. 12:327

USEPA (1998) 40 CFR 141-National Primary Drinking Water Regulations.

USEPA (2017) Secondary Drinking Water Standards: Guidance for Nuisance Chemicals.

Verma R, Dwivedi P (2013) Heavy metal water pollution-A case study Recent research in science and technology 5

Wan Ngah WS, Teong LC, Toh RH, Hanafiah MAKM (2012) Utilization of chitosan-zeolite composite in the removal of $\mathrm{Cu}$ (II) from aqueous solution: Adsorption, desorption and fixed bed column studies. Chem Eng J 209:46-53 doi:https://doi.org/10.1016/j.cej. 2012.07.116

Wang X-s, Qin Y (2005) Equilibrium sorption isotherms for of $\mathrm{Cu} 2+$ on rice bran Process. Biochem. 40:677-680 doi:https://doi.org/ 10.1016/j.procbio.2004.01.043

Weiner ER (2008) Applications of Environmental Aquatic Chemistry: A Practical Guide. CRC Press, Second Edition edn

WHO (2011) Guidelines for Drinking Water Quality

Worch E (2012) Adsorption technology in water treatment: fundamentals, processes and modeling. Walter de Gruyter, Germany

Wu C-H (2007) Adsorption of reactive dye onto carbon nanotubes: Equilibrium, kinetics and thermodynamics. J Hazard Mater 144:93-100 doi:https://doi.org/10.1016/j.jhazmat.2006.09.083

Yahaya L, Akinlabi A (2016) Equilibrium sorption of Lead (II) in aqueous solution onto EDTA-modified Cocoa (Theobroma cacao) Pod husk residue Iranica. J Energy \& Environ 7:58-63

Zeybek Z (2019) Removal of metal pollution in waters by natural adsorbents. Ph.D. Thesis, Konya Technical University, Institue of Graduate Studies

Zeybek Z, Dursun S (2019) Investigation of Cu metal adsorption using acorn caps obtained from Quercus robur L. I J Environ Poll Environ Model 2:259-269

Publisher's Note Springer Nature remains neutral with regard to jurisdictional claims in published maps and institutional affiliations. 